Yannick Mallédant

Manu L. N. G. Malbrain

Daniel A. Reuter

\section{What's new in the management of severe acute pancreatitis?}

Received: 30 April 2015

Accepted: 28 May 2015

Published online: 16 June 2015

(C) The Author(s) 2015. This article is published with open access at Springerlink.com

\section{Y. Mallédant (}

Réanimation Chirurgicale, Service d'Anesthésie Réanimation 1, Hôpital Pontchaillou, 35033 Rennes, France

e-mail: yannick.malledant@chu-rennes.fr

Y. Mallédant

Inserm, U991, Rennes, France

Y. Mallédant

Université de Rennes 1, Rennes, France

\section{L. N. G. Malbrain}

Intensive Care Unit and High Care Burn Unit, Hospital Medical Director Ziekenhuis Netwerk Antwerpen, ZNA Stuivenberg and ZNA St-Erasmus, Lange Beeldekensstraat 267, 2060 Antwerp, Belgium

e-mail: manu.malbrain@skynet.be

\section{A. Reuter}

Department of Anesthesiology, Center of Anesthesiology and Intensive Care Medicine, Hamburg-Eppendorf University Medical Center, Martinistr. 52, 20246 Hamburg, Germany

e-mail: dreuter@uke.de

\section{Introduction}

Acute pancreatitis (AP) is a leading cause of hospitalization for gastrointestinal disorders [1]. Because of a substantially high mortality of up to $20-30 \%$ in severe cases, early identification of patients who might require transfer to an intensive care unit (ICU) is essential [2].

\section{What is new in the assessment of severity?}

The original Ranson criteria from 1974, last modified in 2012, have been followed by several new and in part much more complex scoring systems; however, these have only increased diagnostic performance modestly (AUC from 0.57 to 0.74) [3]. Recent findings suggest that the presence of under- or overweight, development or persistence of organ failure, and assessment of biomarkers, such as cytokine levels might help to further improve identification of high-risk patients [4, 5] (Fig. 1).

\section{What is new in therapy?}

Several interventions have been identified as critical within $48 \mathrm{~h}$, here in particular fluid resuscitation, analgesia and nutritional support.

Fluid therapy

Sustainable scientific and in particular clinical data on how to guide fluid therapy in this disease are still scarce. A recent review underlined the concept of early aggressive resuscitation, guided by the clinical estimation, and the assessment of BUN and haematocrit levels [6]. Recent results from a small retrospective single-centre cohort study seem to support such an aggressive approach in severe AP, whereas data from another, but prospective study reported that excessive hydration $(10-15 \mathrm{ml} / \mathrm{kg} / \mathrm{h})$, where the goal was set to obtain a haematocrit of $35 \%$, resulted in increased organ failure, respiratory insufficiency and mortality $[7,8]$. Whether guiding fluid therapy by cardiac output measurements and/or assessment of fluid responsiveness will lead to improvements in the 
management of this important therapeutic action with positive effects of outcome, as shown in recent experimental studies, needs to be confirmed in clinical settings [9].

\section{Analgesia}

Because of the severity of pain in severe AP, opioids are widely used. However, there is still uncertainty whether their side effect of inducing spasms of the smooth muscles may hide the resolution of the disease or even induce additional pain. Data of a recent Cochrane analysis do not support those concerns, but, as stated by the authors, this analysis is founded only on a very limited number of heterogeneous trials (Cochrane Database Syst Rev Jul 26;7:CD009179).

Epidural anaesthesia, which by far would be most effective in pain control, seems to beneficially influence the course of disease by improving pancreatic microcirculation and tissue oxygenation [10]. However, concerns with regard to concomitant derangements of coagulation and systemic inflammation so far have prevented its broader clinical use.

\section{Nutritional support}

Because enteral nutrition can stimulate pancreatic and intestinal secretions, the pancreatic rest concept has been a dogma in managing severe AP. However, bowel rest is associated with intestinal atrophy, bacterial overgrowth, and is responsible for elevated endotoxin and cytokines levels, bacterial translocation and SIRS induction. This is associated with a higher risk of infected pancreatic necrosis. So, because of its beneficial effects on tissue of the intestinal mucosa and the splanchnic blood flow, the concept that enteral nutrition 'worsens' pancreatitis has diminished greatly over recent years. In a recent metaanalysis including eight randomized controlled studies and 381 patients, enteral nutrition compared with parenteral nutrition decreased infectious complications and mortality [11]. The use of early enteral nutrition (within $48 \mathrm{~h}$ of admission) has proven to be beneficial in patients with AP as it improves clinical outcomes by reducing the number of infections, particularly pancreatic infections (OR 0.49; $95 \%$ CI 0.31-0.78) [12]. Recently, in less severe illness (APACHE II score 11;6\% of the patients with multiple organ failure), a trial did not show the superiority of enteral nutrition within $24 \mathrm{~h}$ compared with oral diet after $72 \mathrm{~h}$, in reducing the rate of infection or death [13]. On the basis of the assumption that gastric food administration increases the risk of abdominal pain exacerbation, nasojejunal feeding has long been favoured. However, exclusive gastric feeding succeeds with the delivery of nutritional targets in $90 \%$ of patients [14]. The type of dietary mixture used did not appear decisive, and the effect of immunonutrition, glutamine supplementation and probiotics has not been demonstrated (Cochrane Database Syst Rev Mar 23;3:CD010605).

\section{How is infected necrosis managed?}

Infected necrosis occurs in $40-70 \%$ of patients in the second or third week of the illness and is the leading cause of late mortality. The onset or worsening of organ failure in a septic context must raise suspicion of infected necrosis, and fine needle CT-guided aspiration should be considered. Antibiotics should be administered as soon as the results of the Gram stain are available. More conservative intervention than surgical necrosectomy now predominates. A step-up approach of percutaneous drainage followed, if necessary, by a minimally invasive surgical necrosectomy significantly reduces the rate of major complications and mortality by $29 \%$ compared with open surgery [15]. Mouli et al. recently reported that a conservative initial approach with antimicrobial therapy with or without PCD was a successful approach for $64 \%$ of patients with infected necrosis [16]. Moreover, postponement of a surgical necrosectomy provides an opportunity for acute collections to become walled-off and liquefied. A randomized study with a very small number of patients requiring secondary pancreatic debridement found endoscopic transgastric necrosectomy to be superior to surgical necrosectomy with respect to the overall rate of major complications or mortality (20 vs. $80 \%)$ [17].

\section{What do we do for biliary pancreatitis?}

Gallstone disease is ranked first among the causes of pancreatitis in all the series (40-70\%) and can progress rapidly to severe AP. Although transabdominal ultrasonography (US) exhibits low sensitivity (ranging from 20 to $50 \%$ ) for detecting choledocholithiasis, repeated examinations indicate an accuracy rate as high as $83 \%$ [18]. However, endoscopic ultrasound is clearly superior, with a sensitivity and specificity greater than $90 \%$ in the detection of bile duct stones. A recent Cochrane Database search found no benefit from early ERCP with respect to mortality and local complications, claiming that ERCP is not needed in patients without evidence of biliary obstruction (Cochrane Database Syst Rev May 16;5:CD009779). In contrast, urgent ERCP within the first $24 \mathrm{~h}$ is indicated in severe AP with co-existing cholangitis or biliary obstruction [19] (Fig. 1). 
Fig. 1 Management of severe pancreatitis. $B M I$ body mass index, $A T B$ antibiotics, $E R C P$ endoscopic retrograde cholangiopancreatography, $A C S$ abdominal compartment syndrome, $P C D$ percutaneous (or endoscopic) drainage

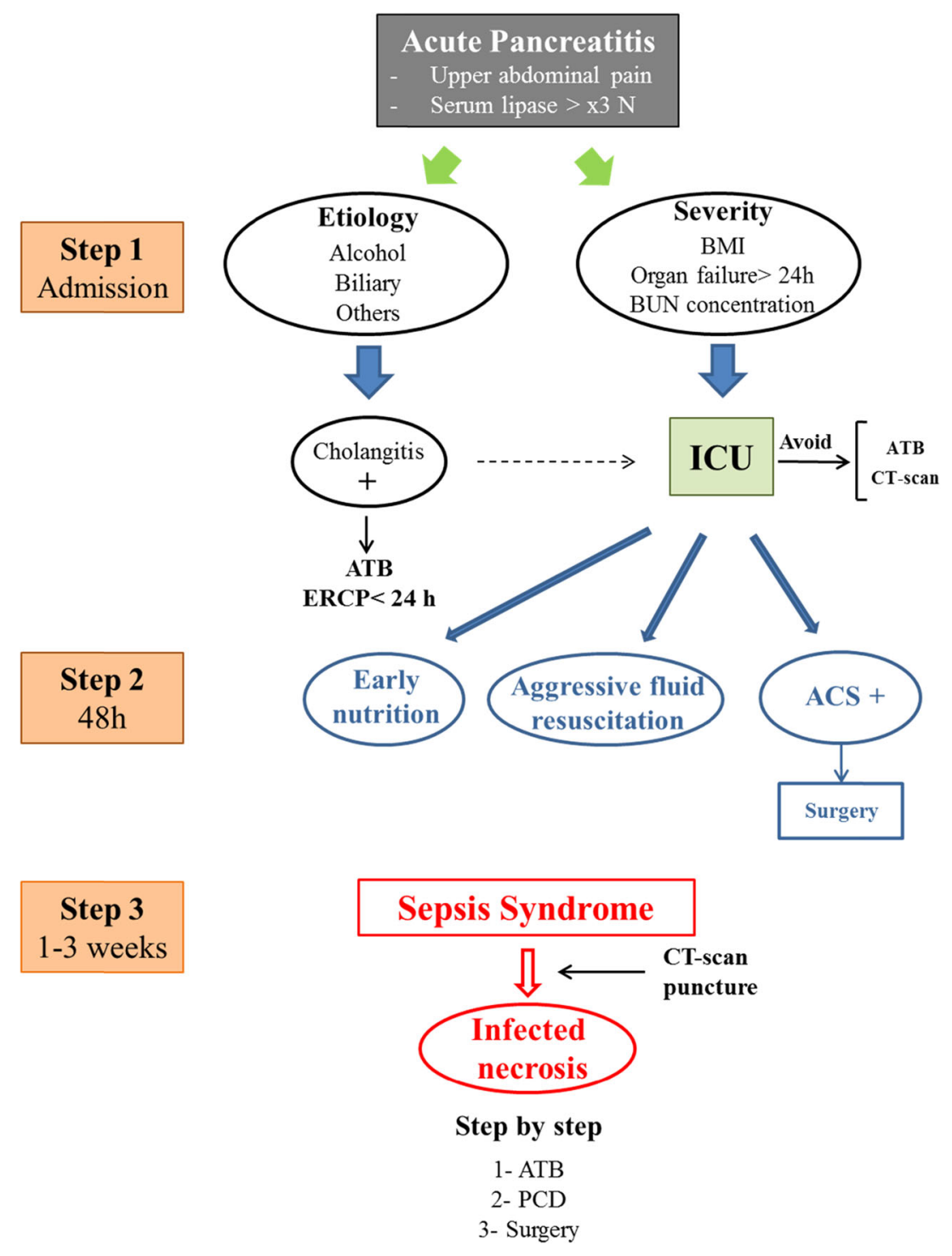

\section{What about intra-abdominal hypertension and abdominal compartment syndrome?}

The overall incidence of intra-abdominal hypertension (IAH) and abdominal compartment syndrome (ACS) in patients with severe AP is around 50-75 and 10-25\%, respectively [20]. The development of IAH and ACS in these patients has a major impact on morbidity and mortality and results from a combined effect of the inflammatory process itself and the iatrogenic aggressive fluid resuscitation. Raised intra-abdominal pressure causes upward shift of both hemidiaphragms and leads to compression atelectasis and hypercapnia. This, in combination with bilateral pleural effusions, may result in severe hypoxia.

When all non-operative measures fail to decrease intra-abdominal pressure and especially in the setting of primary ACS, one should consider immediate midline decompressive laparotomy since this can be life-saving. Newer and less-invasive methods have been recently suggested. A subcutaneous linea alba fasciotomy (SLAF) can be performed by utilizing three short horizontal skin incisions with the peritoneum closed avoiding a true open abdomen. SLAF needs further clinical evaluation and does result in a giant midline hernia with associated need for surgery at a later stage.

Conflicts of interest The authors do not have a conflict of interest.

Open Access This article is distributed under the terms of the Creative Commons Attribution-NonCommercial 4.0 International License (http://creativecommons.org/licenses/by-nc/4.0/), which permits any noncommercial use, distribution, and reproduction in any medium, provided you give appropriate credit to the original author(s) and the source, provide a link to the Creative Commons license, and indicate if changes were made. 


\section{References}

1. Peery AF, Dellon ES, Lund J, Crockett SD, McGowan CE, Bulsiewicz WJ, Gangarosa LM, Thiny MT, Stizenberg K, Morgan DR, Ringel Y, Kim HP, Dibonaventura MD, Carroll CF, Allen JK, Cook SF, Sandler RS, Kappelman MD, Shaheen NJ (2012) Burden of gastrointestinal diseases in the United States: 2012 update. Gastroenterology 143:1179-1187

2. Banks PA, Bollen TL, Dervenis C, Gooszen HG, Johnson CD, Sarr MG, Tsiotos GG, Vege SS, Acute Pancreatitis Classification Working Group (2013) Classification of acute pancreatitis 2012: revision of Atlanta classification and definition by international consensus. Gut 62:102-111

3. Mounzer R, Langmead CJ, Wu BU, Evans AC, Bishehsari F, Muddana V, Singh VK, Slivka A, Whitcomb DC, Yadav D, Banks PA, Papachristou GI (2012) Comparison of existing clinical scoring systems to predict persistent organ failure in patients with acute pancreatitis. Gastroenterology 142:1476-1482

4. Taguchi M, Kubo T, Yamamoto M, Muramatsu K, Yasunaga H, Horiguchi H, Fujimori K, Matsuda S, Fushimi K, Harada M (2014) Body mass index influences the outcome of acute pancreatitis: an analysis based on the Japanese administrative database. Pancreas 43:863-866

5. Nieminen A, Maksimow M, Mentula $P$, Kyhälä L, Kylänpää L, Puolakkainen P, Kemppainen E, Repo H, Salmi M (2014) Circulating cytokines in predicting development of severe acute pancreatitis. Crit Care 18:R104

6. Working Group IAP/APA Acute Pancreatitis Guidelines (2013) IAP/ APA evidence-based guidelines for the management of acute pancreatitis. Pancreatology 13(Suppl 2):e1-e15

7. Wall I, Badalov N, Baradarian R, Iswara K, Li JJ, Tenner S (2011) Decreased morbidity and mortality in patients with acute pancreatitis related to aggressive hydratation. Pancreas 40:547-550

8. Mao EQ, Fei J, Peng YB, Huang J, Tang YQ, Zhang SD (2011) Rapid hemodilution is associated with increased sepsis and mortality among patients with severe acute pancreatitis Chin Med J (Engl) 123:1639-1644
9. Trepte C, Bachmann K, Stork J, Friedheim TJ, Hinsch A, Goepfert MS, Mann O, Izbicki J, Goetz AE, Reuter DA (2013) The impact of early goaldirected fluid management on survival in an experimental model of severe acute pancreatitis. Intensive Care Med 39:717-726

10. Bachmann KA, Trepte CJ, Tomkötter L, Hinsch A, Stork J, Bergmann W, Heidelmann L, Strate T, Goetz AE, Reuter DA, Izbicki JR, Mann O (2014) Effects of thoracic epidural anesthesia on survival and microcirculation in severe acute pancreatitis: a randomized experimental trial. Crit Care 17:R281

11. Yi F, Ge L, Zhao J, Lei Y, Zhou F, Chen Z, Zhu Y, Xia B (2012) Metaanalysis: total parenteral nutrition versus total enteral nutrition in predicted severe acute pancreatitis. Intern Med 51:523-530

12. Li JY, Yu T, Chen GC, Yuan YH, Zhong W, Zhao LN, Chen QK (2013) Enteral nutrition within 48 hours of admission improves clinical outcomes of acute pancreatitis by reducing complications: a meta-analysis. PLoS One 8:e64926

13. Bakker OJ, van Brunschot S, Besselink MG et al (2014) Early versus ondemand nasoenteric tube feeding in acute pancreatitis. N Engl J Med 371:1983-1993

14. Nally DM, Kelly EG, Clarke M, Ridgway P (2014) Nasogastric nutrition is efficacious in severe acute pancreatitis: a systematic review and meta-analysis. Br J Nutr 21:1-10

15. van Santvoort HC, Besselink MG, Bakker OJ, Hofker HS, Boermeester MA, Dejong $\mathrm{CH}$, van Goor $\mathrm{H}$, Schaapherder AF, van Eijck $\mathrm{CH}$, Bollen TL, van Ramshorst $B$, Nieuwenhuijs VB, Timmer R, Laméris JS, Kruyt PM, Manusama ER, van der Harst E, van der Schelling GP, Karsten T, Hesselink EJ, van Laarhoven CJ, Rosman C, Bosscha K, de Wit RJ, Houdijk AP, van Leeuwen MS, Buskens E, Gooszen HG, Dutch Pancreatitis Study Group (2010) A step-up approach or open necrosectomy for necrotizing pancreatitis. N Engl J Med 362:1491-1502
16. Mouli VP, Sreenivas V, Garg PK (2013) Efficacy of conservative treatment, without necrosectomy for infected pancreatitis necrosis: a systematic review and meta-analysis. Gastroenterology 144:333-340

17. Bakker OJ, van Santvoort HC, van Brunschot S, Geskus RB, Besselink MG, Bollen TL, van Eijck CH, Fockens P, Hazebroek EJ, Nijmeijer RM, Poley JW, van Ramshorst B, Vleggaar FP, Boermeester MA, Gooszen HG, Weusten BL, Timmer R, Dutch Pancreatitis Study Group (2012) Endoscopic transgastric vs surgical necrosectomy for infected necrotizing pancreatitis: a randomized trial. JAMA 307:1053-1061

18. Signoretti M, Baccini F, Piciucchi M, Iannicelli E, Valente R, Zerboni G, Capurso G, Delle Fave G (2014) Repeated transabdominal ultrasonography is a simple and accurate strategy to diagnose a biliary etiology of acute pancreatitis. Pancreas 43:1106-1110

19. Fogel EL, Sherman S (2014) ERCP for gallstone pancreatitis. N Engl J Med 370:150-157

20. Kirkpatrick AW, Roberts DJ, De Waele J, Jaeschke R, Malbrain ML, De Keulenaer B, Duchesne J, Bjorck M, Leppaniemi A, Ejike JC, Sugrue M, Cheatham M, Ivatury R, Ball CG, ReintamBlaser A, Regli A, Balogh ZJ, D'Amours S, Debergh D, Kaplan M, Kimball E, Olvera C, Pediatric Guidelines Sub-Committee for the World Society of the Abdominal Compartment Syndrome (2013) Intraabdominal hypertension and the abdominal compartment syndrome: updated consensus definitions and clinical practice guidelines from the World Society of the Abdominal Compartment Syndrome. Intensive Care Med 39:1190-1206 